To Maega | Jurnal Pengabdian Masyarakat

Februari 2022, Vol.5, No.1, hal, 54-62

$\operatorname{ISSN}(P): 2622-6332 ; \operatorname{ISSN}(E): 2622-6340$

http://www.ojs.unanda.ac.id/index.php/tomaega

\title{
Evaluasi Pelaksanaan Kegiatan dan Penyegaran Kader Pro Lansia Pasca Stroke
}

\author{
Lia Dwi Prafitri $1^{*}$, Wahyu Ersila ${ }^{1}$, Nurul Aktifah ${ }^{2}$, Syavira Nooryana ${ }^{2}$, Gigih \\ Setianto ${ }^{2}$ \\ ${ }^{1}$ Program Studi Diploma Tiga Kebidanan, Fakultas IImu Kesehatan, Universitas \\ Muhammadiyah Pekajangan Pekalongan \\ ${ }_{2}^{2}$ Program Studi Sarjana Fisioterapi, Fakultas IImu Kesehatan, Universitas Muhammadiyah \\ Pekajangan Pekalongan \\ ${ }^{*}$ Correspondent Email: L02Prafitri@gmail.com
}

Article History:

Received: 03-11-2021; Received in Revised: 19-11-2021; Accepted: 22-12-2021 DOI: http://dx.doi.org/10.35914/tomaega.v5i1.945

\begin{abstract}
Abstrak
Indonesia merupakan salah satu negara penyumbang insiden stroke terbesar di negara Asia. Evaluasi pelaksanaan kegiatan dan penyegaran kader pro lansia pasca stroke merupakan upaya yang dilakukan untuk menghindari terjadinya faktor resiko stroke dan memastikan pelaksanaan perawatan pasien pasca stroke yang dilakukan oleh kader dapat berjalan dengan baik, sehingga dapat memberikan manfaat yang baik bagi pasien pasca stroke dalam memfasilitasi pasien stroke pada saat pemeriksaan dan penanganan dari tenaga kesehatan. Tujuan pengabdian kepada masyarakat ini adalah sebagai evaluasi tindak lanjut dari pengabdian masyarakat yang telah dilakukan pada tahun 2018 yaitu kegiatan yang telah dilakukan oleh kader untuk mengetahui pelaksanaan perawatan pasien pasca stroke. Metode kegiatan yang dilakukan yaitu dengan melakukan evaluasi menggunakan kuesioner evaluasi pelaksanaan perawatan pasien pasca stroke kepada kader, diskusi mengenai kendala selama pelaksanaan, dan penyegaran materi menggunakan metode ceramah tanya jawab dan demonstrasi. Pengabdian kepada masyarakat ini banyak memberikan manfaat bagi kader pro lansia pasca stroke, bentuk nyatanya adalah adanya peningkatan pengetahuan. Setelah terjadi peningkatan pengetahuan diharapkan tumbuhnya sikap kesadaran akan pentingnya perawatan pasien pasca stroke dan untuk kader pro lansia pasca stroke diharapkan dapat mengaplikasikan ilmu yang diterima dalam kehidupan sehari-hari dan diharapkan dapat terjadi transfer ilmu pengetahuan dari kader terhadap masyarakat sekitar.
\end{abstract}

Kata Kunci: Kader pro lansia, pasca stroke

\section{Abstract}

Indonesia is one of the largest contributor countries in stroke incidence in Asian countries. Evaluation of the implementation of activities and refreshment of pro cadres of seniors post stroke is an effort made to avoid the occurrence of stroke risk factors and ensure the implementation of post-stroke patient care carried out by cadres can run well, so as to provide good benefits for post-stroke patients in facilitating stroke patients at the time of examination and treatment of health workers. The purpose of community service is as a follow-up evaluation of community service that has been done in 2018, namely activities that have been carried out by cadres to find out the implementation of post-stroke patient care. The method of activities carried out is to conduct an evaluation using a questionnaire evaluation of the implementation of post-stroke patient care to cadres, discussion of 
constraints during implementation, and refreshment of materials using question and answer lecture methods and demonstrations. This community service provides many benefits for pro-elderly cadres after stroke, the real form is an increase in knowledge. After an increase in knowledge, it is expected that the growth of awareness of the importance of post-stroke patient care and for pro-stroke cadres post-stroke is expected to apply the knowledge received in daily life and it is expected that there can be a transfer of knowledge from cadres to the surrounding community.

Key Word: Elderly pro cadre, post stroke

\section{Pendahuluan}

World Stroke Organization menunjukkan bahwa untuk setiap tahunnya terdapat kasus baru pasien stroke sebesar 13,7 juta kasus, dan yang mengalami kematian sebesar 5,5 juta akibat dari penyakit stroke. Terdapat 70\% penyakit stroke dan $87 \%$ kematian dan disabilitas karena stroke terjadi pada negara yang memiliki pendapatan rendah dan menengah. Indonesia merupakan salah satu negara penyumbang insiden stroke terbesar di negara Asia. Pada tahun 2013 Angka kejadian stroke di Indonesia sebesar 12,10 per 1000 penduduk. Tahun 2018 Indonesia patut bersyukur karena mengalami penurunan sebesar 10,9 per 1000 penduduk (Kemenkes, 2019).

Stroke merupakan penyakit tidak menular yang bisa menyebabkan kematian. Berdasarkan data (Riskesdas, 2018) bahwa prevalensi stroke paling tinggi terjadi pada usia > 75 tahun yaitu 50,2 permil. Angka kejadian di Perkotaan lebih tinggi dibandingkan dengan di Perdesaan yaitu 12,6: 8,8 permil. Gaya hidup yang terjadi saat ini merupakan penyebab terjadinya stroke, seperti minum alkohol, merokok, kurangnya olahraga dan banyaknya polusi yang ada dilingkungan tempat tinggal. Pencegahan penyakit stroke dapat dilakukan sebagai upaya untuk menghindari resiko yang lebih lanjut (Riskesdas, 2018).

Salah satu faktor resiko yang sering terjadi adalah tekanan darah tinggi yang tidak terkontrol. Untuk menghindari terjadinya faktor resiko stroke sangat diperlukan adanya pendampingan secara berkesinambungan dari kader kesehatan dan tenaga kesehatan. Peran dari kader kesehatan sangat penting untuk dapat memberikan edukasi, memfasilitasi pasien stroke pada saat pemeriksaan dan penanganan dari tenaga kesehatan (Aktifah et al., 2019).

Berdasarkan pengabdian masyarakat yang telah dilakukan pada tahun 2018. Pengetahuan kader mengenai perawatan pasien pasca stroke dirumah adalah memiliki sebelum dilakukan pelatihan memiliki rata-rata nilai 69 dan setelah dilakukan pelatihan memiliki rata-rata nilai 86 artinya mengalami kenaikan nilai sebesar 17 poin. Sedangkan untuk keterampilan yang diperoleh kader dengan adanya pelatihan pembentukan kader pro lansia pasca stroke saat sebelum ke lahan/lapangan memiliki rata-rata nilai 79,30 dan setelah terjun langsung ke lahan praktik memiliki nilai rata 86,75, terjadi peningkatan nilai sebesar 7,45. Hal ini berarti adanya pelatihan kader mampu memberikan dampak yang baik untuk 
peningkatan pengetahuan dan keterampilan kader pro lansia pasca stroke (Aktifah et al., 2019).

Hasil pengabdian kepada masyarakat lain menyatakan bahwa kader kesehatan, khususnya kader Posyandu Penyakit Tidak Menular (PTM) mempunyai peran sangat penting di masyarakat. Kader Kesehatan dapat membantu peran tenaga kesehatan dalam menyampaikan segala informasi terkait dengan kesehatan masayarakat baik dari knowledge, understanding, dan skills kepada masyarakat, khususnya lansia. Informasi yang disampaikan kepada masyarakat yaitu segala upaya pencegahan dan pengendalian penyakit tidak menular yang terjadi pada lansia (Ariyanti et al., 2020).

Penelitian yang dilakukan oleh (Astuti et al., 2020) menyatakan bahwa kader kesehatan mempunyai peranan penting dalam terlaksananya kegiatan posbindu yang ada di masyarakat. Hasil penelitian tersebut menyatakan bahwa dengan adanya pemberian edukasi melalui pelatihan kader kesehatan dapat menambah pengetahuan dan keterampilan kader kesehatan dalam pelaksanaan kegiatan posbindu. Menurut (Astuti et al., 2020) perlu dilakukannya pendampingan kader posbindu sebagai upaya dalam mensukseskan program kegiatan posbindu di masyarakat.

Dari uraian diatas perlu adanya evaluasi tindak lanjut atas kegiatan yang dilakukan oleh kader untuk memastikan pelaksanaan perawatan pasien pasca stroke yang dilakukan oleh kader berjalan dengan baik, sehingga harapannya memberikan manfaat yang baik bagi penerima layanan tersebut yaitu lansia pasca stroke.

\section{Metode}

Pelaksanaan kegiatan pengabdian kepada masyarakat dilakukan di Puskesmas Buaran Kabupaten Pekalongan pada bulan Februari sampai Agustus 2021 dengan peserta sebanyak 20 kader pro lansia pasca stroke. Adapun pengambilan peserta dilakukan secara cluster random sampling yang mewakili dari masing-masing desa sebanyak 2 kader pro lansia. Analisa data yang diperoleh adalah nilai persentase karakteristik peserta dan pengetahuan peserta. Kegiatan pengabdian kepada masyarakat ini dilakukan dengan metode sebagai berikut:

\section{Solusi Permasalahan}

Solusi yang ditawarkan dalam program pengabdian kepada masyarakat ini, adalah: evaluasi kader pro lansia dalam melakukan perawatan pasien lansia pasca stroke setelah 2 tahun pelaksanaan kegiatan, penyegaran materi mengenai stroke dan perawatan pasien pasca stroke pada kader pro lansia untuk menguatkan pengetahuan dan keterampilan kader dalam melaksanakan tugasnya di masyarakat yang berkaitan dengan perawatan lansia pasca stroke.

\section{Metode Pendekatan}

Secara keseluruhan, kegiatan pengabdian kepada masyarakat ini dilakukan dengan metode pendekatan sebagai berikut: evaluasi dengan memberikan kuesioner evaluasi pelaksanaan perawatan pasien pasca stroke kepada kader, diskusi 
mengenai kendala selama pelaksanaan kegiatan perawatan pasien pasca stroke secara mandiri yang sudah pernah dilakukan oleh kader dan penyegaran materi mengenai stroke dan perawatan pasien pasca stroke di rumah dengan metode ceramah tanya jawab dan demonstrasi.

\section{Partisipasi mitra dalam pelaksanaan Program}

Partisipasi mitra dalam pelaksanaan program kegiatan pengabdian kepada masyarakat, diantaranya yaitu: identifikasi masalah mitra melalui wawancara dengan perawat penanggung jawab kader stroke, bekerja sama dengan mitra dalam penyelesaian administrasi dan perijinan, pembuatan undangan yang disampaikan kepada kader, memberikan fasilitas sarana dan prasarana selama kegiatan berlangsung, mendampingi kader selama proses evaluasi dan penyegaran kader, menjawab pertanyaan dan memberikan curah pendapat, membina kader dalam menjalankan perannya sebagai kader pendukung lansia pasca stroke, berdiskusi tentang kendala-kendala yang dialami mitra mengenai pelaksanaan tindak lanjut, dan menjalankan tindak lanjut.

\section{Evaluasi Pelaksanaan dan Keberlanjutan Program}

Evaluasi dan monitoring dilakukan untuk mengetahui sejauh mana informasi yang telah diberikan kepada kader lansia pasca stroke telah berhasil dengan memberikan pre test dan post test, selain itu monitoring dilakukan dengan pendampingan perawat kepada kader setiap kegiatan perawatan pasien pasca stroke di masing-masing wilayah kerja.

\section{Hasil dan Pembahasan}

Hasil pengambilan data yang diperoleh pada kegiatan pengabdian masyarakat ini dapat disajikan pada tabel berikut ini.

Tabel 1. Karakteristik Peserta

\begin{tabular}{lcc}
\hline \multicolumn{1}{c}{ Karakteristik } & Frekuensi & Persentase (\%) \\
\hline Umur & 3 & 15 \\
$<35$ tahun & 17 & 85 \\
$>35$ tahun & & \\
\hline Pendidikan & 1 & 5 \\
Tamat SD & 4 & 20 \\
Tamat SMP & 14 & 70 \\
Tamat SMA & 1 & 5 \\
Tamat PT & & \\
\hline Pekerjaan & 15 & 75 \\
Tidak bekerja & 5 & 25 \\
Bekerja & & \\
\hline
\end{tabular}

Dari tabel di atas dapat diketahui bahwa Sebagian besar yaitu 17 peserta $(85 \%)$ berumur $>35$ tahun dengan tamat SMA sebanyak 14 peserta $(70 \%)$, dan 
tidak bekerja sebanyak 15 peserta (75\%). Tingkat pendidikan yang sudah ditempuh cukup baik yaitu SMA. Hal ini sejalan dengan pernyataan (Astuti et al., 2020) bahwa tingkat Pendidikan yang cukup baik sangat mendukung kemampuan sebagai kader dimana pendidikan dapat mempengaruhi pengetahuan seseorang. Menurut (Dunggio et al., 2021), peningkatan pengetahuan dan keterampilan kader setelah mengikuti pelatihan dapat ditunjang dari Pendidikan formal yang dimiliki kader yaitu Sebagian besar mempunyai Pendidikan terakhir sekolah menengah atas.

Hasil kegiatan evaluasi pelaksanaan kegiatan dan penyegaran kader pro lansia pasca stroke terdapat peningkatan pengetahuan sebelum dan setelah dilakukan kegiatan penyegaran kader. Hasil pengetahuan kader dapat disajikan dalam tabel sebagai berikut:

Tabel 2. Pengetahuan Peserta

\begin{tabular}{lcccc}
\hline Pengetahuan & \multicolumn{2}{c}{ Sebelum } & \multicolumn{2}{c}{ Setelah } \\
\cline { 2 - 5 } & $\mathbf{N}$ & $\mathbf{\%}$ & $\mathbf{N}$ & $\mathbf{\%}$ \\
\hline Cukup & 11 & 55 & 3 & 15 \\
\hline Baik & 9 & 45 & 17 & 85 \\
\hline Total & $\mathbf{2 0}$ & $\mathbf{1 0 0}$ & $\mathbf{2 0}$ & $\mathbf{1 0 0}$ \\
\hline
\end{tabular}

Berdasarkan tabel di atas dapat diketahui bahwa pengetahuan kader sebelum dilakukan penyegaran 55\% mempunyai pengetahuan cukup dan setelah dilakukan penyegaran $85 \%$ mempunyai pengetahuaan yang baik. Menurut (Huriyati et al., 2019) indikator keberhasilan peningkatan pengetahuan kader dalam pelaksanaan pelatihan kader dapat diketahui dari rata-rata nilai pre test dan post test. Dalam kegiatan penyegaran kader ini, proses yang dilakukan adalah penyampaian materi dengan menggunakan media power poin dan demonstrasi sehingga dapat meningkatkan pengetahuan kader. Kader sangat antusias dengan materi yang diberikan, hal ini terlihat dari adanya keaktifan bertanya dan menjawab saat kegiatan berlangsung. Berikut adalah gambar pada saat kegiatan pengabdian kepada masayarakat. 


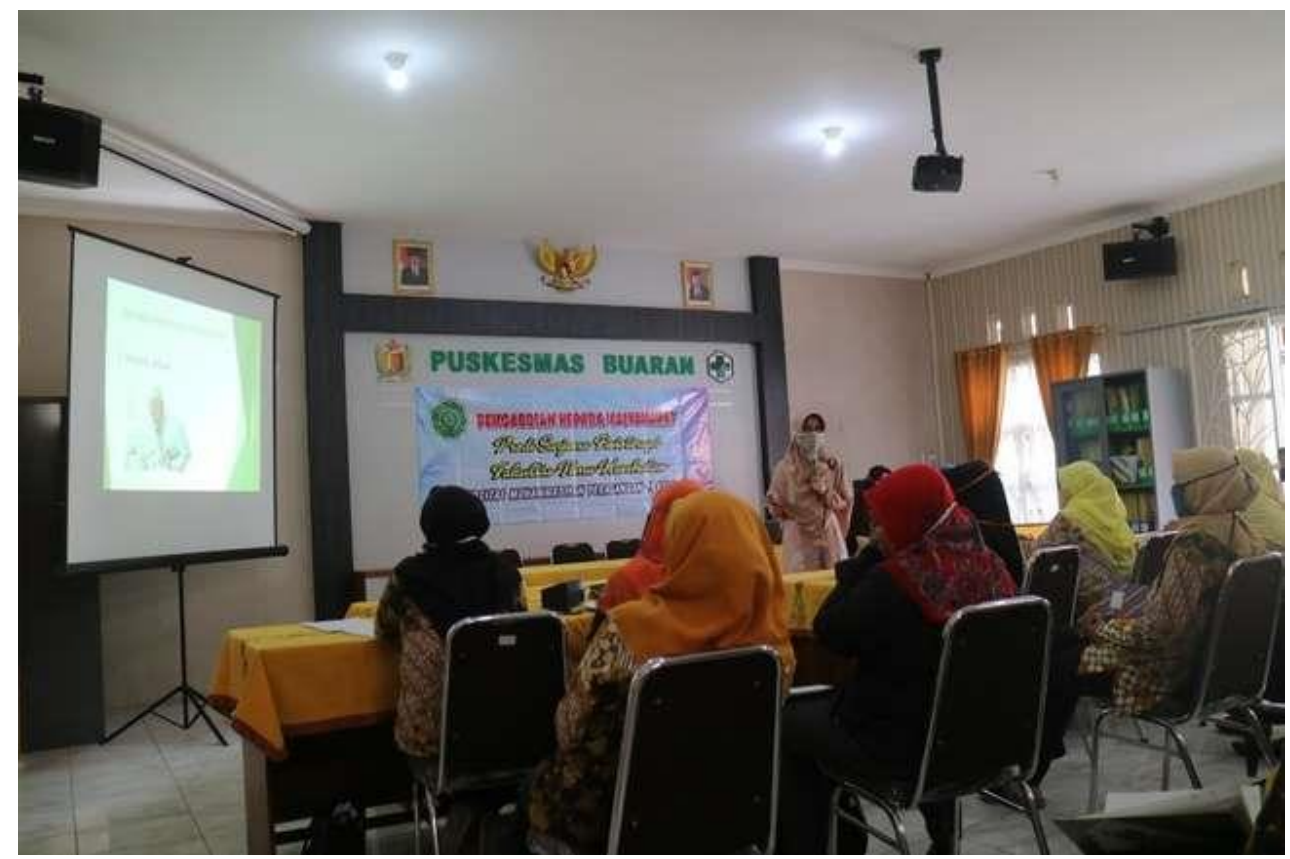

Gambar 1. Penyampaian Materi

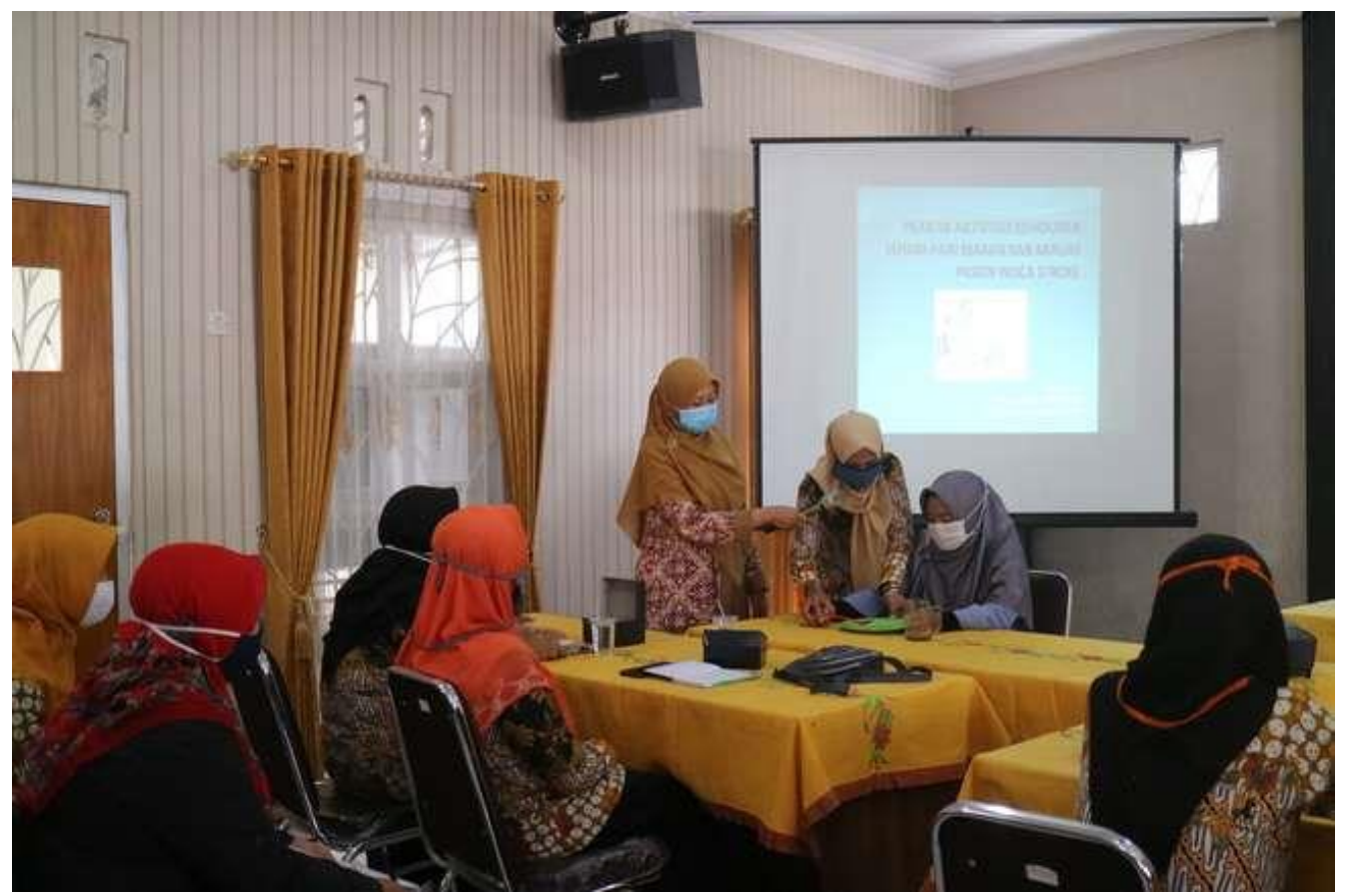

Gambar 2. Demonstrasi Praktik Makan dan Minum Pasien Pasca Stroke 


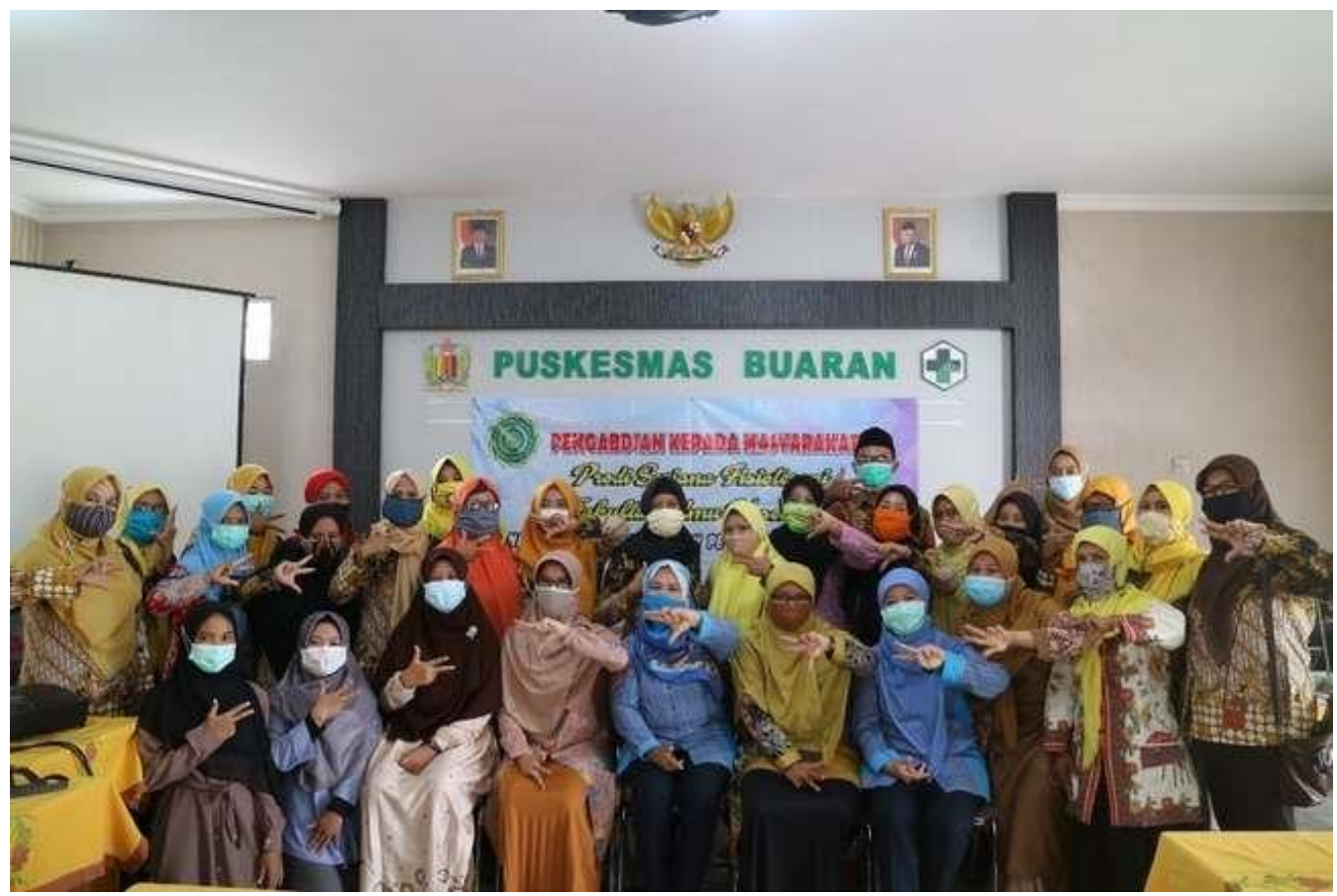

Gambar 3. Tim pengabdian kepada masyarakat dan peserta

Berdasarkan hasil kegiatan dapat diketahui bahwa terjadi peningkatan pengetahuan kader sebelum dan setelah dilakukan penyegaran materi. Hal ini sesuai dengan pernyataan (Suryani et al., 2021) bahwa terjadi peningkatan pengetahuan dengan skor 11,07 setelah dilakukan pelatihan kader dalam pencegahan penyakit tidak menular (PTM). Menurut (Indarjo et al., 2019) mengatakan hal sama bahwa setelah dilakukan pelatihan pada kader posbindu lansia didapatkan hasil evaluasi yang menunjukkan adanya peningkatan skor pengetahuan post test dan peningkatan keterampilan kader dalam melakukan pemeriksaan fisik dan pemeriksaan laboratorium sederhana. Hasil kegiatan pengabdian kepada masyarakat yang dilakukan oleh (Juhdeliana et al., 2018) bahwa terdapat perbedaan signifikan rerata nilai pengetahuan osteoporosis sebelum dan sesudah penyuluhan. Pernyataan lain menyatakan bahwa terdapat peningkatan prosentase tingkat pengetahuan peserta penyakit stroke setelah pemberian materi penyuluhan tentang mengenal penyakit stroke (Lindawati et al., 2019).

Penerapan metode ceramah tanya jawab dan demonstrasi mampu meningkatkan pengetahuan kader. Hal ini sejalan dengan pernyataan (Zaki et al., 2018) bahwa peningkatan pengetahuan kader dapat disebabkan karena metode yang digunakan yaitu kombinasi antara metode konvensional ceramah dengan simulasi. Hasil pengabdian masyarakat lain oleh (Fitriahadi \& Khusnul, 2019) menyatakan bahwa penggunaan metode ceramah, tanya jawab dan diskusi dapat meningkatkan kemampuan kader dalam mengoptimalkan program posyandu lansia di wilayah Betokan. Setelah dilakukan pelatihan kader dapat memahami pemeriksaan dan deteksi dini permasalahan pada lansia. Hasil pengabdian kepada masyarakat yang lain menyatakan bahwa pelatihan terapi "Paket BAHAGIA" dengan menggunakan aplikasi android dapat meningkatkan keterampilan kader dan keluarga dalam merawat pasien stroke (Handayani et al., 2020). 
Pelaksanaan kegiatan pengabdian kepada masyarakat ini dilaksanakan sebagai upaya untuk meningkatkan pelayanan kesehatan pasien pasca stroke oleh kader ksehatan. Hal yang sama juga disampaikan oleh (Nikmah \& Khomsatun, 2020) bahwa peningkatan pelayanan kesehatan lanjut usia diperlukan untuk mewujudkan lansia yang sehat, berkualitas, dan produktif pada masa tuanya. Kader kesehatan berperan sebagai penggerak masyarakat berperan penting dalam upaya meningkatkan derajat kesehatan masyarakat, khususnya pasien pasca stroke.

\section{Kesimpulan}

Pengabdian kepada masyarakat ini banyak memberikan manfaat bagi kader pro lansia pasca stroke, bentuk nyatanya adalah adanya peningkatan pengetahuan dan terlaksananya perawatan pasien pasca stroke yang dilakukan oleh kader dapat berjalan dengan baik. Setelah terjadi peningkatan pengetahuan diharapkan tumbuhnya sikap kesadaran akan pentingnya perawatan pasien pasca stroke dan untuk kader pro lansia pasca stroke diharapkan dapat mengaplikasikan ilmu yang diterima dalam kehidupan sehari-hari dan diharapkan dapat terjadi transfer ilmu pengetahuan dari kader terhadap masyarakat sekitar. Perlu adanya keberlanjutan pendampingan dan penyegaran kader untuk meningkatkan pengetahuan dan keterampilan kader.

\section{Ucapan Terimakasih}

Ucapan terimakasih kami sampaikan kepada Lembaga Penelitian dan Pengabdian Masyarakat (LPPM), Dinas Kesehatan Kabupaten Pekalongan, Puskesmas Buaran serta kader pro lansia yang telah mendukung pelaksanaan kegiatan pengabdian kepada masayarakat di Puskesmas Buaran.

\section{Daftar Pustaka}

Aktifah, N., Ersila, W., Prafitri, L. D., \& Sabita, R. (2019). Meningkatkan Kemandirian Pasien Pasca Stroke Melalui In-House Training Kader Pendukung Lansia Pasca Stroke. Indonesian Journal of Community Services, 1(1), 95-104.

Ariyanti, R., Preharsini, I. A., \& Sipolio, B. W. (2020). Edukasi Kesehatan Dalam Upaya Pencegahan dan Pengendalian Penyakit Hipertensi Pada Lansia. To Maega: Jurnal Pengabdian Masyarakat, 3(2), 74-82.

Astuti, F. D., Rokhmayanti, \& Hastuti, S. K. W. (2020). Pelatihan Kader Sebagai Upaya Peningkatan Pengetahuan Kader tentang Pos Pembinaan Terpadu (Posbindu). Prosiding Seminar Nasional UNIMUS, 3(1), 761-769.

Dunggio, A. R. S., Hitijahubessy, C. N. M., \& Setyowati, S. E. (2021). Trainning of Fasilitator Bagi Kader Kesehatan Program Penyakit Tidak Menular dalam Pencegahan dan Pengendalian Potensi Stroke. Poltekita: Jurnal Pengabdian Masyarakat, 2(1), 21-27.

Fitriahadi, E., \& Khusnul, L. (2019). Program Kemitraan Masyarakat tentang Pelatihan Kader Posyandu Lansia di Wilayah Betokan, Tirtoadi, Godean, Sleman. Jurnal Pengabdian Masyarakat Kebidanan, 1(2), 5-10.

Handayani, F., Widyastuti, R. H., \& Eridani, D. (2020). Terapi "Paket Bahagia" 
Berbasis Teknologi Informasi Sebagai Tatalaksana Perawatan Pasien Stroke Di Rumah Bagi Keluarga Yang Merawat Dan Kader Kesehatan Di Kelurahan Pudak Payung: Pengabdian Kepada Masyarakat. Jurnal Ilmu Keperawatan Komunitas, 3(1), 35-39.

Huriyati, E., Ratrikaningtyas, P. D., Projosasmito, S. R., \& Farmawati, A. (2019). Kader Hidup Sehat dalam Upaya Promotif Penyakit Denegeratif. Journal of Community Empowerment for Health, 2(1), 36-42.

Indarjo, S., Hermawati, B., \& Nugraha, E. (2019). Upaya Pelatihan Pos Pembinaan Terpadu Penyakit Tidak Menular (posbindu ptm) pada Kader Posyandu Di Desa Kalikayen, Kec. Ungaran Timur, Kab. Semarang. Jurnal Abdimas, 23(2), 134-138.

Juhdeliana, J., Marlyn, S, R., Berthy, T, E., Agustina, T., \& Butar-Butar, J. (2018). Screening Pada Lansia dan Pelatihan Kader Posbindu Rw 07 Wilayah Binaan Puskesmas Bencongan Indah Karawaci Tangerang. Prosiding PKM-CSR, 1, 795-804.

Kemenkes, R. (2019). Carpal tunnel syndrome pada kehamilan. Pusat Data Dan Informasi.

Lindawati, N. Y., Kurniawati, E., Puspitasari, D., \& Pratimasari, D. (2019). Peningkatan Kualitas Hidup Lansia dalam Penanganan Stroke bagi Kader PKK dan Kesehatan di Gilingan, Banjarsari, Surakarta. Jurnal Surya Masyarakat, 1(2), 139-145.

Nikmah, K., \& Khomsatun, M. (2020). Pelatihan Kader Lansia Dalam Upaya Peningkatan Pelayanan Kesehatan Lansia Pada Keluarga. Journal of Community Engagement in Health, 3(2), 210-216.

Riskesdas. (2018). Hasil Utama Riskesdas 2018. Badan Penelitian Pengembangan dan Kesehatan.

Suryani, D., Simbolon, D., Jumiyati, \& Yandrizal. (2021). Pelatihan Kader dalam Pencegahan Penyakit Tidak Menular (PTM) di Wilayah Puskesmas Anggut Atas Kota Bengkulu. Prosiding Pengabdian Masyarakat Poltekkes Kemenkes Tasikmalaya, 107-112.

Zaki, I., Farida, F., \& Sari, H. P. (2018). Peningkatan Kapasitas Kader Posyandu Melalui Pelatihan Pemantauan Status Gizi Balita. Jurnal Pengabdian Kepada Masyarakat (Indonesian Journal of Community Engagement), 3(2), 169-177. 